\title{
Phytoprotection
}

\section{Relative fitnes of herbicide-resistant and susceptible biotypes of weeds}

\section{S.I. Warwick et L.D. Black}

Volume 75, numéro 4, 1994

Herbicide Resistance Workshop - Edmonton, Alberta - 9 and 10 december 1993

Atelier sur la résistance aux herbicides - Edmonton (Alberta) - 9 et 10 décembre 1993

URI : https://id.erudit.org/iderudit/706070ar

DOI : https://doi.org/10.7202/706070ar

Aller au sommaire du numéro

\section{Éditeur(s)}

Société de protection des plantes du Québec (SPPQ)l

\section{ISSN}

0031-9511 (imprimé)

1710-1603 (numérique)

Découvrir la revue

\section{Citer cet article}

Warwick, S. \& Black, L. (1994). Relative fitnes of herbicide-resistant and susceptible biotypes of weeds. Phytoprotection, 75(4), 37-49.

https://doi.org/10.7202/706070ar
Résumé de l'article

$\mathrm{Au}$ cours des dernières années, il y a eu une augmentation rapide du nombre de mauvaises herbes (plus de 100) signalées comme étant résistantes aux herbicides, de même qu'une augmentation du nombre de groupes d'herbicides auxquels la résistance a évolué. Cet article fait état des données qui suggèrent l'existence de différences d'aptitude entre les biotypes résistants et sensibles aux herbicides. Des estimés de l'aptitude sont nécessaires afin d'établir des modèles de population fiables. Ces estimés permettent de prévoir le potentiel de succès évolutif d'un génotype basé sur sa survie, sa compétitivité et en dernier lieu, sur son succès reproductif. Les différences d'aptitude entre les biotypes résistants et sensibles sont généralement dérivées des mesures de productivité relative ou de compétitivité. Pour les mauvaises herbes résistantes aux triazines, des études ont démontré que les plantes résistantes étaient généralement moins compétitives que les plantes sensibles, malgré la présence de certaines exceptions. Bien qu'il y ait moins de données disponibles sur l'aptitude des plantes résistantes aux groupes herbicides autres que les triazines, cet article résume l'information disponible sur les sulfonylurées, les urées substituées, les dinitroanilines, le paraquat, le diclofop et les arsenicaux organiques. Aucune différence d'aptitude constante n'a été observée pour les biotypes résistants et sensibles aux herbicides autres que les triazines. En général, les études ont démontré que l'aptitude relative des biotypes sensibles et résistants d'une espèce donnée dépend des conditions biologiques (incluant la variation à l'intérieur du génotype et de la populationet la compétition interet intra-biotypes), et des conditions environnementales telles la température, la qualité lumineuse et les pratiques de gestion.
Ce document est protégé par la loi sur le droit d'auteur. L’utilisation des services d'Érudit (y compris la reproduction) est assujettie à sa politique d'utilisation que vous pouvez consulter en ligne.

https://apropos.erudit.org/fr/usagers/politique-dutilisation/ 


\title{
Relative fitness of herbicide-resistant and susceptible biotypes of weeds
}

\author{
Suzanne I. Warwick and Lynn D. Black ${ }^{1}$
}

Received 1993-10-20; accepted 1994-04-06

In recent years, there has been a rapid increase in the number of reported cases of herbicide-resistant weed species (over 100), as well as an increase in the types of herbicides to which resistance has evolved. This paper reviews evidence for differential fitness of herbicide-resistant and susceptible biotypes. Fitness estimates are required to produce reliable population models. Fitness measures describe the potential evolutionary success of a genotype based on survival, competitive ability and ultimately reproductive success. Differences in relative fitness between resistant and susceptible biotypes are usually inferred from measures of relative plant productivity or competitiveness. For triazine-resistant weed species, studies have indicated that resistant plants were generally less fit than susceptible plants, although exceptions did exist. Although less data are available on the fitness of plants resistant to non-triazine herbicides, information is summarized for sulfonylureas, substituted ureas, dinitroanilines, paraquat, diclofop, and organic arsenicals. No consistent differences in relative fitness were observed for non-triazine resistant and susceptible biotypes. In general, studies have indicated that the relative fitness of susceptible and resistant biotypes of a single species depends upon biological conditions, including genotype and population variation, intra- and inter-biotype competition, and environmental conditions such as temperature, light quality, and management practices. Future needs for relative fitness studies are discussed.

\section{Warwick, S.I. et L.D. Black. Aptitude relative de biotypes de mauvaises herbes résistants et sensibles aux herbicides. PHYTOPROTECTION 75 (Suppl.): 37-49.}

Au cours des dernières années, il y a eu une augmentation rapide du nombre de mauvaises herbes (plus de 100) signalées comme étant résistantes aux herbicides, de même qu'une augmentation du nombre de groupes $d^{\prime}$ herbicides auxquels la résistance a évolué. Cet article fait état des données qui suggèrent l'existence de différences d'aptitude entre les biotypes résistants et sensibles aux herbicides. Des estimés de l'aptitude sont nécessaires afin d'établir des modèles de population fiables. Ces estimés permettent de prévoir le potentiel de succès évolutif d'un génotype basé sur sa survie, sa compétitivité et en dernier lieu, sur son succès reproductif. Les différences d'aptitude entre les biotypes résistants et sensibles

1. Centre for Land and Biological Resources Research, Agriculture Canada, K.W. Neatby Bldg., C.E.F., Ottawa, Ontario, Canada K1A OC6 
sont généralement dérivées des mesures de productivité relative ou de compétitivité. Pour les mauvaises herbes résistantes aux triazines, des études ont démontré que les plantes résistantes étaient généralement moins compétitives que les plantes sensibles, malgré la présence de certaines exceptions. Bien qu'il y ait moins de données disponibles sur l'aptitude des plantes résistantes aux groupes herbicides autres que les triazines, cet article résume l'information disponible sur les sulfonylurées, les urées substituées, les dinitroanilines, le paraquat, le diclofop et les arsenicaux organiques. Aucune différence d'aptitude constante n'a été observée pour les biotypes résistants et sensibles aux herbicides autres que les triazines. En général, les études ont démontré que l'aptitude relative des biotypes sensibles et résistants d'une espèce donnée dépend des conditions biologiques (incluant la variation à l'intérieur du génotype et de la population et la compétition inter- et intra-biotypes), et des conditions environnernentales telles la température, la qualité lumineuse et les pratiques de gestion.

\section{Nomenclature of chemical names cited in the text:}

Atrazine: 6-chloro-N-ethyl-N-(1-methylethyl) -1,3,5-triazine-2,4-diamine; chlorsulfuron: 2-chloro$\mathrm{N}$-[[(4-methoxy-6-methyl-1,3,5-triazin-2-yl)amino]carbonyl]benzenesulfonamide; chlorotoluron: 3-(3-chloro-p-tolyl)-1,1-dimethylurea; diclofop: ( \pm )-2-[4-(2,4-dichlorophenoxy)phenoxyJpropanoic acid; paraquat: 1,1'-dimethyl-4,4'-bipyridinium ion; simazine: 6 chloro-N,N-diethyl-1,3,5-triazine-2,4-diamine; trifluralin: 2,6-dinitro-N,N-dipropyl-4(trifluoromethyl)benzenamine.

\section{INTRODUCTION}

Since the discovery of a triazineresistant biotype of Senecio vulgaris L. in the United States (Ryan 1970), there has been a rapid increase in the number of reported cases of herbicide-resistant weed species and also an increase in the types of herbicides to which resistance has evolved. There are over 100 weed species with biotypes known to be resistant to herbicides (Holt and LeBaron 1990; LeBaron and Gressel 1982; Moss and Rubin 1993; Warwick 1991). Herbicide resistance may be defined as the condition whereby a plant withstands the normal field dose of a herbicide, as a result of selection and genetic response to repeated exposure to herbicides with a similar mode of action. Susceptible plants are normally killed by recommended field doses.

The weed population/herbicide model is an excellent tool for studying selection, adaptation and evolution since herbicide selection pressure is easy to study within a specific environment (Warwick 1991). Characteristics of herbicides, and their use that increase the selection pressure for herbicide resistance, include: i) herbicides with a single target and specific mode of action, an increased activity and effectiveness in killing a wide range of weed species, and a season-long residual control of germinating weeds; and ii) herbicides which are applied frequently, over several growing seasons of the weed population without rotation or combination with other types of herbicides. Indeed, the majority of herbicides for which there are documented cases of resistance exhibit these characteristics. In most instances with triazines, resistance appeared after $7 \mathrm{yr}$ or more, with dinitroanilines after $10 \mathrm{yr}$, with paraquat after $5 \mathrm{yr}$ or more, while sulfonylurea resistance appeared after only 3 to 5 yr (Warwick 1991).

Differential fitness of resistant and susceptible biotypes was recognized as an important factor influencing the evolution of herbicide resistance long before resistance to triazine herbicides evolved (Harper 1956). In a herbicidefree environment, resistant biotypes can be less, more, or as fit as susceptible biotypes. When a resistant biotype is less fit than a susceptible biotype, 
discontinued use of the selective herbicide allows natural selection to restore the predominance of susceptible plants. The larger the fitness differences, the more rapid susceptible plants will replace resistant ones. If there are no fitness differences between the two biotypes or if the resistant biotype is more fit, stoppage of the use of the selective herbicide will not result in the elimination of the resistant biotype. Differences in relative fitness will, therefore, influence the selection of herbicide resistance management strategies. Differential fitness is also one of the prime factors affecting the potential ecological impact of the escape of herbicide resistance from transgenic crops into wild or weedy populations through hybridization and introgression, or simply as new crop escapes.

The present paper reviews evidence for the relative fitness of herbicideresistant and susceptible biotypes of weeds. This topic is of considerable agronomic interest given its important implications for the management of herbicide-resistant weeds.

\section{RELATIVE FITNESS}

Fitness measures describe the potential evolutionary success of a genotype based on survival, competitive ability and ultimately reproductive success, with the most fit individual leaving the greatest number of offspring and thereby contributing a greater proportion of its genes to the gene pool of the population. Practically, fitness differences between resistant and susceptible biotypes are usually determined from measures of relative plant productivity or competitiveness (Holt 1990; Radosevich and Holt 1982; Warwick 1991). Relative fitnesses are calculated by assigning a fitness value of 1 to the most fit biotype, i.e. the one with the highest productivity or greatest competitiveness. Differences between the relative fitness of the most fit biotype and that of the less fit biotype is termed the selection coefficient. The cost of resistance in a herbicide-free environment is the ratio of the performance of the resistant biotype over the performance of the susceptible biotype $\left(P_{r}: P_{s}\right)$, and selection against the resistant biotype equals $1-\left(P_{r}: P_{s}\right)$. In the presence of the herbicide, selection against the susceptibe biotype equals $1-\left(P_{s}: P_{r}\right)$ and will equal 1.0 if resistance is complete.

The earliest relative fitness studies of herbicide-resistant and susceptible biotypes were conducted with only single populations, that often originated from widely separated areas. Later studies conducted more critical tests, including estimates of both inter- and intra-population variability of each biotype and effects of geographical origin (Haigler et al.1994; Murphy et al. 1986; Warwick and Marriage 1982; Weaver et al. 1982). Recent studies also include comparisons of biotypes of similar genetic background, either from the same field population or as isogenic lines. If isogenic plant material is not used, general consideration must be given to levels of population variability within weed species, and a range of susceptible and resistant populations should be included in the study (Warwick 1991). For example, Darmency et al. (1992) examined the relationship of inter- and intra-population variation in Chenopodium album $\mathrm{L}$. as regards the mutation on the psbA gene that confers triazine resistance and the accompanying decrease in the chlorophyll a:chlorophyll $b$ (chla:chlb) ratio. Their studies indicated considerable genetic variability for the chla:chlb ratio among plants within a susceptible population and among populations of the species. The magnitude of chla:chl $b$ differences was greater than that due to the influence of the mutation itself, i.e. $10 \%$ decrease for isogenic resistant plant material.

Recent studies by Dekker and Burmester (1992) have suggested both an ontogenetic and diurnal influence on the relative photosynthetic characteristics of triazine-resistant and susceptible plants, i.e. the photosynthetic superiority of one biotype relative to the other was a function of the time of day and of the age of the plant. Younger resistant plants of Brassica napus L. had greater photosynthetic rates early and late in the 
diurnal light period, whereas those of susceptible plants were greater during midday, as well as during the photoperiod as a whole. The relationship between the two biotypes dramatically changed with the onset of the reproductive phase, when the resistant plants had greater photosynthetic rates than susceptible plants during all periods of the diurnal light period. These observations suggest that resistant plants may have a fitness advantage over susceptible plants in certain unfavourable ecological niches independent of the triazine herbicides, such as cool, low-light environments. These studies also indicate that relative fitness measures are highly dynamic and are influenced not only by genotype, but also by the stage of plant development of that genotype, and on a very small environmental scale, by time of day.

Relative fitness estimates are required to produce reliable population models. Most relative fitness studies have usually restricted measurements to vegetative and reproductive growth, while recent population models (Maxwell et al. 1990; Mortimer et al. 1992; Putwain and Mortimer 1989) emphasize evaluation for a number of life-history stages: seed dormancy and germination, seedling establishment, survival, growth, pollination, and seed production.

\section{Triazines}

The evolution of weed species resistant to triazines has become widespread with ca. 55 resistant species reported in Canada, Europe and the United States (Warwick 1991). Triazine herbicides are strong inhibitors of photosynthesis, and resistance in most weedy species results from a loss of herbicide binding ability due to alteration of the binding site on the thylakoid membrane of the chloroplast (Warwick 1991). The first relative fitness studies were conducted by Conard and Radosevich (1979), who reported that susceptible plants of Senecio vulgaris and Amaranthus powellii S. Wats. (reported as $A$. retroflexus $\mathrm{L}$.) had greater above-ground dry matter production and greater seed production than resistant plants, when grown under both competitive and noncompetitive conditions in the absence of atrazine. Subsequent studies have supported the hypothesis that triazineresistant plants are generally less fit than susceptible plants, although some exceptions do exist (Holt 1990; Warwick 1991). Reduced productivity or competitiveness of the resistant biotypes are reported for several weed species (Table 1).

The correlation of reduced plant vigour with triazine resistance has also been observed in engineered triazine-resistant crops, with $20-30 \%$ yield reductions in resistant cultivars of Brassica napus (Beversdorf et al. 1988) and Setaria italica (L.) Beauv. (Darmency and Pernès 1989; Reboud and TillBottraud 1991; Ricroch et al. 1987).

In Abutilon theophrasti Medic., the mechanism of triazine resistance is different from the species listed above and involves herbicide detoxification through enhanced metabolism. Nevertheless, non-competitive experiments of Bailey and Garbutt (1991) found that while resistant individuals of A. theophrasti had lower biomass and lower photosynthetic capacity than susceptible individuals, there was no significant difference in seed mass or seed number between the biotypes. Under competitive conditions, the results suggested that, in general, the resistant plants were inferior, but that both frequency and density had marked effects on the competitive outcome (Bailey and Garbutt 1991).

The use of nuclear-isogenic lines allows for the study of the effects of the mutation conferring herbicide resistance separate from other genetic differences. Similar yield reductions in the triazine-resistant cultivars of Brassica napus were evident when examined in either a similar (Gressel and Ben-Sinai 1985) or common nuclear-genetic background (Beversdorf et al. 1988). Isogenic studies of triazineresistant Senecio vulgaris conducted on $F_{1}$ hybrids and backcrossed plants (McCloskey and Holt 1990; Stowe and Holt 1988) also presented data supporting reduced productivity of resistant biotypes, with the actual percentage of reduction in yield dependent on the nuclear genome and 
time of harvest. For example, Stowe and Holt (1988) found that although the susceptible parental line outperformed the resistant parental plant in all growth parameters, differences between the reciprocal $F_{1}$ plants $(S \times R, R \times S)$ tended to converge over time, with the cost of resistance ca. $60 \%$ at $6 \mathrm{wk}, 30 \%$ at 8 wk, and $0-2 \%$ at 10 wk. Time of harvest will influence results if susceptible biotypes develop faster than resistant biotypes, as shown for example in Brassica rapa L. (Mapplebeck et al. 1982), Chenopodium album (Marriage and Warwick 1980) and Senecio vulgaris (Holt and Radosevich 1983) The differences between biotypes will diminish with time as the growing season progresses. Relative fitness studies of isogenic lines of Chenopodium album (Darmency and Gasquez 1990) indicated that both intermediate and resistant biotypes flowered later and produced fewer seed than the susceptible biotype. However, intermediate plants at the seedling stage grew more vigorously than either susceptible or resistant plants.

Studies by Jordan (1992) compared the fitness effects of triazine resistance in similar nuclear backgrounds in Amaranthus hybridus L. from Virginia and Maryland, with the use of reciprocal $F_{2}$ progeny derived from selfing of $F_{1}$ hybrids, both in the greenhouse and in a mixed weed community in the field. Reduced biomass production and associated fitness cost was evident for the resistant plants, but the magnitude of the cost of resistance (i.e. the ratio of biomass of resistant plants: biomass of susceptible plants) varied sharply among populations and environments. For example, in the greenhouse, cost of resistance in the Virginia population increased from 24 to $35 \%$ with competition and increased further still

Table 1. Weed species exhibiting reduced productivity or competitiveness of triazine-resistant biotypes

\begin{tabular}{|c|c|c|}
\hline Species & Country & Reference \\
\hline Amaranthus cruentus $\mathrm{L}$. & Spain & De Prado et al. (1991) \\
\hline Amaranthus hybridus L. & $\begin{array}{l}\text { United States } \\
\text { Spain }\end{array}$ & $\begin{array}{l}\text { Ahrens and Stoller (1983) } \\
\text { Jordan (1992) } \\
\text { De Prado et al. (1991) }\end{array}$ \\
\hline Amaranthus powellii S. Wats. & $\begin{array}{l}\text { United States } \\
\text { Canada }\end{array}$ & $\begin{array}{l}\text { Radosevich and Holt (1982) } \\
\text { Weaver and Warwick (1982) } \\
\text { Weaver et al. (1982) }\end{array}$ \\
\hline Amaranthus retroflexus $\mathrm{L}$. & Canada & $\begin{array}{l}\text { Weaver and Warwick (1982) } \\
\text { Weaver et al. (1982) }\end{array}$ \\
\hline Brassica rapa L. & Canada & Mapplebeck et al. (1982) \\
\hline Chenopodium album L. & $\begin{array}{l}\text { Belgium } \\
\text { Hungary } \\
\text { Canada }\end{array}$ & $\begin{array}{l}\text { Bulcke et al. (1985) } \\
\text { Solymosi and Lehoczki (1989) } \\
\text { Marriage and Warwick (1980) } \\
\text { Warwick and Black (1981) } \\
\text { Warwick and Marriage (1982) } \\
\text { Leroux (1993) }\end{array}$ \\
\hline Poa annua L. & Belgium & Bulcke et al. (1984) \\
\hline Polygonum lapathifolium L. & France & Gasquez et al. (1981) \\
\hline Senecio vulgaris $\mathrm{L}$. & $\begin{array}{l}\text { Czechoslovakia } \\
\text { United States } \\
\text { Canada }\end{array}$ & $\begin{array}{l}\text { Chodová and Mikulka (1992) } \\
\text { Holt (1988) } \\
\text { Holt and Radosevich (1983) } \\
\text { Warwick (1980) }\end{array}$ \\
\hline Setaria glauca (L.) Beauv. & Spain & De Prado et al. (1992) \\
\hline Solanum nigrum L. & $\begin{array}{l}\text { Belgium } \\
\text { Italy }\end{array}$ & $\begin{array}{l}\text { Bulcke et al. (1985) } \\
\text { Zanin and Lucchin (1990) }\end{array}$ \\
\hline
\end{tabular}


(>50\%) in the field trial. In contrast, in the Maryland population grown in the greenhouse, there was no measurable cost of resistance in the absence of competition and smaller cost differences $(18 \%)$ in the presence of competition. Reboud and Till-Bottraud (1991) measured the cost of resistance in two nearly isogenic lines of Setaria italica by conducting a competition experiment over a range of densities in the absence of herbicide treatment. Susceptible individuals were better competitors, but the cost of resistance was density dependent and increased with density. The cost also varied with the characters measured. It was highest (65\%) for seed production estimates compared to shoot height or shoot weight at the higher density for resistant individuals.

Not all triazine-resistant biotypes demonstrated reduced vigour and competitiveness. In Chenopodium strictum Roth., a late-flowering, slower-growing species, resistant and susceptible biotypes produced similar amounts of biomass in both competitive and non-competitive conditions (Warwick and Black 1981). Similarly, one study of Chenopodium album reported similar rates of photosynthetic activity for the two biotypes with the resistant one being a better competitor than the susceptible one (Jansen et al. 1986). The resistant biotype of Phalaris paradoxa L. was either equal or superior to the susceptible one in photosynthetic potential and growth under noncompetitive conditions (Schönfeld et al. 1987).

The relative productivity of susceptible and resistant biotypes of a single species may also depend upon environmental conditions, including light quality and temperature. Results of field trials testing differential growth of the triazine-resistant and susceptible biotypes to light vary. In a study of Amaranthus hybridus grown under non-competitive conditions at three light levels, the growth rate did not differ between biotypes at $10 \%$ light, whereas at $40 \%$ and $100 \%$ light, biomass of the resistant biotype was $40 \%$ less than that of the susceptible one (Ahrens and Stoller 1983). In contrast, the resistant biotypes of Brassica spp. were always less productive than the susceptible ones regardless of light quality conditions (Hobbs 1987). Similarly, studies by Hart et al. (1992) reported that under high photon flux densities (PFD), growth response between nearly isonuclear triazineresistant and susceptible plants of Brassica napus, as measured by dry weight and biomass allocation, was $30-40 \%$ greater for the susceptible biotype compared to the resistant one. However, under low PFD there was little difference in dry weight and biomass allocation between the two biotypes. The differences in growth under high PFD are likely due to the greater photo-inhibitory sensitivity of resistant plants. The similarity in growth response observed under low PFD was probably due to similar rates of photo synthesis in susceptible and resistant plants. The inefficient photochemistry of resistant plants is not necessarily reflected in inhibition of whole plant growth.

Reports also vary with respect to differential biotype response to temperature. An increased heat and $\mathrm{pH}$ sensitivity of the photosynthetic apparatus was evident in several triazine-resistant biotypes, including isogenic nuclear lines of resistant Solanum nigrum L., suggestive of a greater instability of the oxygen evolving system in resistant plants at higher temperatures (Warwick 1991). Several studies have suggested less of a competitive disadvantage for triazine-resistant biotypes at lower temperatures. For example, triazineresistant cultivars of Setaria italica indicated no biotype differences at $17^{\circ} \mathrm{C}$, whereas at $27^{\circ} \mathrm{C}$, the usual differential between biotypes was observed (Darmency and Pernès 1989; Ricroch et al. 1987). Similarly, for Polygonum lapathifolium L., the 20$50 \%$ growth differential of resistant and susceptible biotypes in total biomass, observed under warm greenhouse conditions, was reduced to $4 \%$ under cool conditions (Gasquez et al. 1981). The latter result was consistent with enhanced low temperature germination in resistant biotypes of 
Polygonum lapathifolium and Amaranthus retroflexus $\mathrm{L}$. observed in the same study. A resistant biotype of Phalaris paradoxa displayed more vigorous growth than the susceptible biotype when grown under early winter conditions (Schönfeld et al. 1987). In contrast, studies of Amaranthus hybridus indicated that the susceptible biotypes were more vigorous at lower temperatures than resistant ones (Vencill et al. 1987).

Other studies have indicated no correlation between differential biotype productivity and temperature, for example, in resistant biotypes of Chenopodium album from different geographical origins (Vencill et al. 1987). Similarly, temperature was not observed to elicit photosynthetic differences between triazine-resistant and susceptible biotypes of Brassica spp. (Hobbs 1987), nor to differentially affect the relative growth of resistant and susceptible biotypes of Solanum nigrum (Jacobs et al. 1988) (the latter was evaluated in a common nuclear genetic background by parental lines and reciprocal $F_{1}$ crosses). There was also no differential temperature effect on biomass production of nearly isonuclear triazine-resistant and susceptible plants of Senecio vulgaris (McCloskey and Holt 1991). The lack of consistent temperature-related effects among triazine-resistant species may reflect the importance of the nuclear genome in determining temperature response.

Reports of differences in seed dormancy between resistant and susceptible biotypes may vary depending on species and growth conditions. Some studies have shown that the resistant biotype has greater dormancy or later germination than susceptible biotypes (Bulcke et al. 1984, 1985; Mapplebeck et al. 1982; Weaver and Thomas 1986). Others suggest no correlation in dormancy with resistance (Bulcke et al. 1985; Weaver and Thomas 1986) or report variable results depending on conditions (Gasquez et al. 1981). Studies by Bailey and Garbutt (1994) showed that the susceptible biotype of Abutilon theophrasti had both a greater rate of germination and greater total germination percentage in the majority of treatment/environment combinations, with differences between biotypes accentuated at $25^{\circ} \mathrm{C}$. However, in some environments there were no biotype differences in germination characteristics.

Alternative weed management practices and the accompanying changes in environmental conditions may also have an effect on measures of relative fitness. The role of such factors was revealed in a comparison of seeds and adult plants in a mixed simazineresistant and susceptible population of Senecio vulgaris on a fruit farm in the United Kingdom (Watson et al. 1987). Two seed banks were identified, each having a different effect on biotype maintenance. Seeds of the resistant biotype had greater longevity than those of the susceptible biotype in the lower seedbank ( $>2 \mathrm{~cm}$ depth), while in the surface bank (0-2 cm), biotypes showed different longevity according to management practice, i.e. substantial net contribution to the seed bank by the resistant biotype with simazine treatment, and by the susceptible biotype under rototilling. Cultivation practices that place seeds at greater depths will result in a depletion of the susceptible biotype at faster rates than the resistant biotype. In the surface seed bank, it was the fate of the adult plants and their relative seed yield that determined the relative success of the two biotypes.

\section{Non-triazine herbicides}

Although less data are available on the relative fitness of plants resistant to non-triazine herbicides, information is summarized for sulfonylureas, substituted ureas, dinitroanilines, paraquat, diclofop, and organic arsenicals.

\section{Sulfonylureas}

Sulfonylurea herbicides inhibit acetolactate synthase (ALS) which catalyzes the first step of the biosynthesis of branched chain amino acids. Resistance is due to an altered site of action and a form of acetolactate synthase that is insensitive to inhibition (Warwick 1991). Reports on differential fitness 
vary relative to source populations. Studies by Christoffoleti and Westra (1991) on sulfonylurea-resistant and susceptible populations of Kochia scoparia (L.) Schrad. from Colorado indicated that in greenhouse studies, under non-competitive conditions, the susceptible plants produced more biomass than did the resistant plants. The data from field experiments conducted by the same authors at different densities and competitive levels also confirmed the lower competitive ability of the resistant plants. In contrast, Mallory-Smith et al. (1992) and Thompson and Thill (1992) concluded that the sulfonylurea-resistant biotypes of $K$. scoparia from Kansas and North Dakota were not less competitive than the susceptible ones. Their studies showed that the resistant biotype from Kansas accumulated similar biomass in comparative growth studies, while the resistant biotype from North Dakota tended to accumulate more biomass than its susceptible counterpart, and that under competitive conditions, the Kansas resistant biotype was more competitive, producing ca. $50 \%$ more biomass than the susceptible one, averaged over all densities. Field observations and growth chamber experiments indicated that sulfonylurearesistant $K$. scoparia from Montana germinates more rapidly than susceptible plants in the absence of the herbicide, particularly at lower temperatures (Dyer et al. 1993).

Fitness studies on sulfonylurea-resistant and susceptible Lactuca serriola L. from Idaho by Alcocer-Ruthling et al. (1992 a, 1992b) found no differences in seed longevity, fecundity or seed viability between the two biotypes, although seeds from the resistant biotype germinated as fast or faster than those from susceptible plants. Comparative greenhouse trials indicated that the susceptible plants had a $52 \%$ faster growth rate and also produced $24 \%$ more biomass. Similarly in competitive growth studies, the susceptible biotype produced $31 \%$ more above-ground biomass than the resistant biotype, when averaged over all densities.
Crop studies indicate that plant fitness may be unaffected by sulfonylurea resistance. Field trials of transgenic sulfonylurea-resistant Linum usitatissimum L. carried out in Saskatchewan indicated no significant differences between the transgenic lines and the parent for any agronomic trait in the absence of the herbicide (McHughen and Holm 1991). Studies in France on chlorsulfuron resistance transferred into wild $\mathrm{Ci}$ chorium spp. from the crop indicated that all measured growth and reproductive characteristics were identical for resistant and susceptible biotypes of wild populations (Lavigne and Gasquez 1992). Similarly, Brassica napus resistant to imidazolinones, a separate class of ALS-inhibiting herbicides, exhibited similar seed yield, maturity, and disease tolerance to the susceptible biotype (Swanson et al. 1989), as was the case for shoot height in imidazolinone- and sulfonylurea-resistant mutants of Zea mays L. (Anderson and Georgeson 1989). However, the agronomic performance of two sulfonylurea-resistant transgenic lines of Nicotiana tabacum L. grown under field conditions in Ontario indicated that both transgenics were lower yielding than the controls in the absence of the herbicide treatment (Brandle and Miki 1993).

\section{Substituted ureas}

No evidence of inferior growth rate was observed in chlorotoluron-resis-tant Alopecurus myosuroides Huds. from the United Kingdom and Israel (Chauval and Gasquez 1991). Studies by Mortirner et al. (1992) on chlorotoluron-resistant populations of $A$. myosuroides from the United Kingdom indicated that relative fitness, as measured from seed production, was shown to be both frequency and density dependent in experiments comparing resistant and susceptible biotypes in mixtures with winter wheat (Triticum aestivum L.). For example, in control plots, the susceptible biotype outcompeted the resistant one at low densities, but was selected against at high intra-biotype densities. The form of this interaction and the consequent selection against the susceptible biotype was also strongly 
influenced by the two rates of chlorotoluron applied. At the highest rate, selection coefficients were greater than 0.87 and tended to increase with increasing sowing density of the susceptible biotype, and decrease with increasing sowing density of the resistant one, while at the half rate, selection was always against the susceptible biotype although not as pronounced.

\section{Dinitroanilines}

Dinitroaniline herbicides inhibit the formation of microtubules and thereby block mitosis in susceptible plants, with resistance conferred by an altered form of tubulin that results in microtubule insensitivity to the herbicides. Fitness studies (Murphy et al. 1986) under non-competitive conditions on several populations of dinitroanilineresistant and susceptible biotypes of Eleusine indica (L.) Gaertn. from South Carolina, have indicated no significant differences between biotypes in terms of most growth and development characteristics, with the exception of significantly greater inflorescence weight in the susceptible biotype. Studies by Valverde et al. (1988) indicated no differences in vegetative biomass or growth rate among three dinitroaniline-resistant and susceptible populations of $E$. indica from North Carolina, South Carolina and Mississippi, although reproductive weight of the susceptible plants was higher than that of resistant plants. Competition studies (intra- and inter-biotype) of the above species by the latter authors suggested that the resistant biotype was less competitive than susceptible plants, responding to competition by reduced reproductive output (Valverde et al. 1988).

The preliminary results from recently described trifluralin-resistant Setaria viridis (L.) Beauv. from Manitoba (I. Morrison, personal communication) indicated no measurable differences in relative fitness or reproductive effort between resistant and susceptible populations.

\section{Paraquat}

Studies in Japan on the growth of paraquat-resistant and -susceptible biotypes of Erigeron canadensis (L.) Cronq. indicated that the susceptible biotype was more vigorous than the resistant biotype under non-competitive conditions in the absence of paraquat (Itoh and Matsunaka 1990). Studies by Tucker and Powles (reported in Powles and Howat 1990) indicated that the relative fitness (inter- and intra-specific competitive ability) of paraquat-resistant Hordeum glaucum Steud. from Australia was lower than that of the susceptible biotype in the absence of paraquat.

\section{Diclofop}

Reduced fitness of diclofop-resistant biotypes of Lolium rigidum Gaudin. from Australia was also reported, the relative fitness of the resistant biotype being 0.81 when grown in pure stands and 0.65 when grown in mixed stands with susceptible plants (Powles and Howat 1990).

\section{Organic arsenicals}

Haigler et al. (1994) compared three organic arsenical-resistant and four susceptible populations of Xanthium strumarium L. from South Carolina under non-competitive field conditions over two growing seasons and found that susceptible and resistant biotypes were similar in reproductive potential, and in growth and development.

\section{FUTURE NEEDS}

The evidence summarized in this review indicates that generalities, as regards the relative fitness of herbicide-resistant weeds, are difficult and must take into consideration biological conditions, i.e. genotype/population source and geographically-based variability of the weed species, intraand inter-biotype competition, and the effects of the environment (temperature, light, management practices, etc.). Relative fitness studies should include either multiple populations of each biotype or isogenic lines. Competition experiments should address relative fitness both in the early vegetative phases, including seed and seedling survivorship, and in the reproductive phase. Relative fitness studies should also be 
done in the field, and include competition with crop plants and perhaps other weed species. In addition to the effects of selection pressure imposed by herbicide application, more field data are required on the selective effects of other agronomic practices (such as crop rotation, herbicide mixtures, post- versus pre-emergence herbicide applications, and inter-row cultivation) on the relative fitness, establishment and spread of resistant populations. Additional studies testing response to light, temperature and other environmental conditions are also needed on a wide range of herbicide-resistant species.

Given this variation in relative fitness, case by case studies are required to assess the ecological impact of the escape of herbicide resistance from transgenic crops. Such a quantitative experimental study of the invasiveness of a herbicide-resistant transgenic crop (glufosinate-tolerant Brassica napus) has been recently reported (Crawley et al. 1993). Experiments were carried out over $3 \mathrm{yr}$ in 12 different habitats at three sites within the United Kingdom, and showed that interspecific plant competition proved to be the main determinant of the finite rate of population increase, i.e. measure of invasiveness, rather than the genetic lines tested. One might predict that the risks of increased invasiveness, in association with the acquisition of herbicide resistance through gene escape, would be a more significant factor in already highly invasive species such as weedy species.

\section{ACKNOWLEDGEMENTS}

We wish to thank Jeff Anderson (Ottawa University, Ottawa) for providing a translation of the abstract and for reviewing the manuscript; and Cliff Crompton (Agriculture Canada, Ottawa) for his comments on an earlier version of the manuscript.

\section{REFERENCES}

Ahrens, W.H., and E.W. Stoller. 1983. Competition, growth rate, and $\mathrm{CO}_{2}$ fixation in triazine-susceptible and resistant smooth pigweed (Amaranthus hybridus). Weed Sci. 31: 438-444.

Alcocer-Ruthling, M., D.C. Thill, and B. Shafii. 1992a. Differential competitiveness of sulfonylurea resistant and susceptible prickly lettuce (Lactuca serriola). Weed Technol. 6: 303-309.

Alcocer-Ruthling, M., D.C. Thill, and B. Shafii. 1992b. Seed biology of sulfonylurearesistant and -susceptible biotypes of prickly lettuce (Lactuca serriola). Weed Technol. 6: 858-864.

Anderson, P.C., and M. Georgeson. 1989. Herbicide-tolerant mutants of corn. Genome 31: 994-999.

Bailey, B.A., and K. Garbutt. 1991. Competitive interactions between atrazineresistant and atrazine-susceptible biotypes of Abutilon theophrasti Medic. Am. J. Bot. [Suppl.] 78(6): 47-48 (Abstract).

Bailey, B.A., and K. Garbutt 1994. The ecology of atrazine resistant and susceptible biotypes of Abutilon theophrasti Medic.: I. Germination biology. J. Appl. Ecol. (in press).

Beversdorf, W.D., D.J. Hume, and M.J. Donnelly-Vanderloo. 1988. Agronomic performance of triazine-resistant and susceptible reciprocal spring canola hybrids. Crop Sci. 28: 932-934.

Brandle, J.E., and B.L. Miki. 1993. Agronomic performance of sulfonylurea-resistant transgenic flue-cured tobacco grown under field conditions. Crop Sci. 33: 847851.

Bulcke, R., H. De Praeter, M. Van Himme, and J. Stryckers. 1984. Resistance of annual meadow-grass, Poa annua L., to 2-chloro-1,3,5-triazines. Meded. Fac. Landbouwwet. Rijksuniv. Gent 49/3b: 1041-1050.

Bulcke, R., J. De Vleeschauwer, J. Vercruysse, and J. Stryckers. 1985. Comparison between triazine-resistant and -susceptible biotypes of Chenopodium album L. and Solanum nigrum L. Meded. Fac. Landbouwwet. Rijksuniv. Gent 50/2a: 211220.

Chauval, B., and J. Gasquez. 1991. Study of the growth of herbicide-resistant blackgrass populations. Pages 431-432 in J.C. Caseley, G.W. Cussans, and R.K. Atkin (eds.), Herbicide resistance in weeds and crops. Butterworth- Heinemann, Oxford, England. 
Chodová, D., and J. Mikulka. 1992. Comparing some biological and physiological differences of susceptible and resistant common groundsel (Senecio vulgaris L.). Ochr. Rostl. 28: 263-272.

Christoffoleti, P.J., and P. Westra. 1991. Fitness and ecological adapatability of chlorsulfuron resistant and susceptible kochia biotypes. Proc. West. Soc. Weed Sci. 44: 81 (Abstract).

Conard, S.G., and S.R. Radosevich. 1979. Ecological fitness of Senecio vulgaris and Amaranthus retroflexus biotypes susceptible or resistant to atrazine. J. Appl. Ecol. 16: 171-177.

Crawley, M.J., R.S. Hails, M. Rees, D. Kohn, and J. Buxton. 1993. Ecology of transgenic oilseed rape in natural habitats. Nature (London) 363: 620-623.

Darmency, H., and J. Gasquez. 1990. Appearance and spread of triazine resistance in common lambsquarters (Chenopodium album). Weed Technol. 4: 173-177.

Darmency, H., and J. Pernès. 1989. Agronomic performance of a triazine resistant foxtail millet (Setaria italica (L.) Beauv.). Weed Res. 29: 147-150.

Darmency, H., B. Chauvel, J. Gasquez, and A. Matejicek. 1992. Variation of chlorophyll $a / b$ ratio in relation to population polymorphism and mutation of triazineresistance. Plant. Physiol. Biochem. (Paris) $30: 57-63$.

Dekker, J.H., and R.G. Burmester. 1992. Pleiotropy in triazine-resistant Brassica napus - Ontogenetic and diurnal influences on photosynthesis. Plant Physiol. 100: 2052-2058.

De Prado, R., M. Sanchez, and C. Dominguez. 1991. Resistance to $s$-triazines in Amaranthus cruentus and A. hybridus II. Photosynthetic activity, growth and productivity. Meded. Fac. Landbouwwet. Rijksuniv. Gent 56/3a: 807-812.

De Prado, R., J. Menéndez, M. Tena, and C. Dominguez. 1992. Growth and productivity of Setaria glauca resistant and susceptible to atrazine. Pages $465-470$ in $1 X^{e}$ Colloque international sur la biologie des mauvaises herbes, 1992. Dijon and Paris, France. ANPP.

Dyer, W.E., P.W. Chee, and P.K. Fay. 1993. Rapid germination of sulfonylurea-resistant Kochia scoparia L. accessions is associated with elevated seed levels of branched chain amino acids. Weed Sci. 41: 18-22.

Gasquez, J., H. Darmency, and J.P. Compoint. 1981. Comparaison de la germination et de la croissance de biotypes sensibles et résistants aux triazines chez quatre espèces de mauvaises herbes. Weed Res. 21: 219-225.
Gressel, J., and G. Ben-Sinai. 1985. Low intraspecific competitive fitness in a triazine-resistant, nearly nuclear-isogenic line of Brassica napus. Plant Sci. 38: 2932.

Haigler, W.E., B.J. Gossett, J.R. Harris, and J.E. Toler. 1994. Growth and development of organic arsenical-susceptible and -resistant common cocklebur (Xanthium strumarium) biotypes under noncompetitive conditions. Weed Sci. (in press).

Harper, J.L. 1956. The evolution of weeds in relation to resistance to herbicides. Proc. $3^{\text {rd }} \mathrm{Br}$. Weed Control Conf. 1: 179-188.

Hart, J.J., S.R. Radosevich, and A. Stemler. 1992. Influence of light intensity on growth of triazine-resistant rapeseed (Brassica napus). Weed Res. 32: 349-356.

Hobbs, S.L.A. 1987. Comparison of photosynthesis in normal and triazine-resistant Brassica. Can. J. Plant Sci. 67: 457466.

Holt, J.S. 1988. Reduced growth, competitiveness and photosynthetic efficiency of triazine-resistant Senecio vulgaris from California. J. Appl. Ecol. 25: 307-318.

Holt, J.S. 1990. Fitness and ecological adaptability of herbicide-resistant biotypes. Pages 419-429 in M.B. Green, H.M. LeBaron, and W.K. Moberg (eds.), Managing resistance to agrochemicals from fundamental research to practical stategies. Am. Chem. Soc. Symp. Ser. 421, Washington, DC.

Holt, J.S., and H.M. LeBaron. 1990. Significance and distribution of herbicide resistance. Weed Technol. 4: 141-149.

Holt, J.S., and S.R. Radosevich. 1983. Differential growth of two common groundsel (Senecio vulgaris) biotypes. Weed Sci. 31: 112-120.

Itoh, K., and S. Matsunaka. 1990. Parapatric differentiation of paraquat resistant biotypes in some Compositae species. Pages 33-49 in S. Kawano (ed.), Biological approaches and evolutionary trends in plants. Academic Press, London.

Jacobs, B.F., J.H. Duesing, J. Antonovics, and D.T. Patterson. 1988. Growth performance of triazine-resistant and -susceptible biotypes of Solanum nigrum over a range of temperatures. Can. J. Bot. 66: 847-850.

Jansen, M.A.K., J.H. Hobé, J.C. Wesselius, and J.J.S. Van Rensen. 1986. Comparison of photosynthetic activity and growth performance in triazine-resistant and susceptible biotypes of Chenopodium album. Physiol. Vég. 24: 475-484. 
Jordan, N. 1992. Relative biomass production of triazine-resistant and susceptible reciprocal $\mathrm{F}_{2} \mathrm{~s}$ of smooth pigweed (Amaranthus hybridus L.) under greenhouse and field conditions. Proc. Weed Sci. Soc. Am. 32: 44 (Abstract).

Lavigne, C., and J. Gasquez. 1992. Risques de dispersion d'un gène de résistance au chlorsulfuron à partir d'une culture d'endives résistantes. Pages 497-505 in $I X^{e}$ Colloque international sur la biologie des mauvaises herbes, 1992. Dijon and Paris, France, ANPP.

LeBaron, H.M., and J. Gressel (eds.). 1982. Herbicide resistance in plants. Wiley, New York. 401 pp.

Leroux, G.D. 1993. Relative fitness of $s$-triazines susceptible and resistant biotypes of Chenopodium album. Phytoprotection 74: 143-151.

Mallory-Smith, C.A., D.C. Thill, M. AlcocerRuthling, and C.R. Thompson. 1992. Growth comparisons of sulfonylurea resistant and susceptible biotypes. Proc. $1^{\text {st }}$ Int. Weed Control Congr., Melbourne, Australia. 2: 301-303.

Mapplebeck, L.R., V. Souza Machado, and B. Grodzinski. 1982. Seed germination and seedling growth characteristics of atrazine-susceptible and resistant biotypes of Brassica campestris. Can. J. Plant Sci. 62: 733-739.

Marriage, P.B., and S.I. Warwick. 1980. Differential growth and response to atrazine between and within susceptible and resistant biotypes of Chenopodium album L. Weed Res. 20: 9-15.

Maxwell, B.D., M.L. Roush, and S.R. Radosevich. 1990. Predicting the evolution and dynamics of herbicide resistance in weed populations. Weed Technol. 4: 213.

McCloskey, W.B., and J.S. Holt. 1990. Triazine resistance in Senecio vulgaris parental and nearly isonuclear backcrossed biotypes is correlated with reduced productivity. Plant Physiol. 92: 954962.

McCloskey, W.B., and J.S. Holt. 1991. Effect of growth temperature on biomass production of nearly isonuclear triazine-resistant and -susceptible common groundsel (Senecio vulgaris L.). Plant Cell Environ. 14: 699-705.

McHughen, A., and F. Holm. 1991. Herbicide resistant transgenic flax field test: agronomic performance in normal and sulfonylurea-containing soils. Euphytica 55: $49-56$
Mortimer, A.M., P.F. Ulf-Hansen, and P.D. Putwain. 1992. Modelling herbicide resistance - a study of ecological fitness. Pages 148-164 in I. Denholm, A.L. Devonshire, and D.W. Hollomon (eds.), Resistance '91: achievements and developments in combating pesticide resistance. Elsevier, London.

Moss, S.R., and B. Rubin. 1993. Herbicideresistant weeds: a worldwide perspective. J. Agric. Sci. 120: 141-148.

Murphy, T.R., B.J. Gossett, and J.E. Toler. 1986. Growth and development of dinitroaniline-susceptible and -resistant goosegrass (Eleusine indica) biotypes under non competitive conditions. Weed Sci. 34: 704-710.

Powles, S.B., and P.D. Howat. 1990. Herbicide-resistant weeds in Australia. Weed Technol. 4: 178-185.

Putwain, P.D., and A.M. Mortimer. 1989. The resistance of weeds to herbicides: rational approaches for containment of a growing problem. Proc. Br. Crop Prot. Conf. Weeds 1: 285-294.

Radosevich, S.R., and J.S. Holt. 1982. Physiological responses and fitness of susceptible and resistant weed bio-types to triazine herbicides. Pages 163-183 in H.M. LeBaron, and J. Gressel (eds.), Herbicide resistance in plants. Wiley, New York.

Reboud, X., and I. Till-Bottraud. 1991. The cost of herbicide resistance measured by a competition experiment. Theor. Appl. Genet. 82: 690-696.

Ricroch, A., M. Mousseau, H. Darmency, and J. Pernès. 1987. Comparison of triazineresistant and -susceptible cultivated $\mathrm{Se}$ taria italica: growth and photosynthetic capacity. Plant Physiol. Biochem. (Paris) 25: $29-34$

Ryan, G.F. 1970. Resistance of common grounsel to simazine and atrazine. Weed Sci. 18: 614-616.

Schönfeld, M., T. Yaacoby, O. Michael, and B. Rubin. 1987. Triazine resistance without reduced vigor in Phalaris paradoxa. Plant Physiol. 83: 329-333.

Solymosi, P., and E. Lehoczki. 1989. Characterization of a triple (atrazine-pyrazonpyridate) resistant biotype of common lambsquarters (Chenopodium albumL.). J. Plant Physiol. 134: 685-690.

Stowe, A.E., and J.S. Holt. 1988. Comparison of triazine-resistant and -susceptible biotypes of Senecio vulgaris and their $F_{1}$ hybrids. Plant Physiol. 87: 183-189.

Swanson, E.B., M.J. Herrgessell, M. Arnoldo, D.W. Sippell, and R.S.C. Wong. 1989. Microspore mutagenesis and selection: canola plants with field tolerance to the imidazolinones. Theor. Appl. Genet. 78: 525-530. 
Thompson, C.R., and D.C. Thill. 1992. Sulfonylurea herbicide-resistant and -susceptible kochia (Kochia scoparia (L.) Schrad.) growth rate and seed production. Proc. Weed Sci. Soc. Am. 32: 44 (Abstract).

Valverde, B.E., S.R. Radosevich, and A.P. Appleby. 1988. Growth and compet-itive ability of dinitroaniline-herbicide resistant and susceptible goosegrass (Eleusine indica) biotypes. Proc. West. Weed Sci. Soc. 41: 81 (Abstract).

Vencill, W.K., C.L. Foy, and D.M. Orcutt. 1987. Effects of temperature on triazine-resistant weed biotypes. Environ. Exp. Bot. 27: 473-480.

Warwick, S.I. 1980. Differential growth between and within triazine-resistant and triazine-susceptible biotypes of Senecio vulgaris L. Weed Res. 20: 299-303.

Warwick, S.I. 1991. Herbicide resistance in weedy plants: physiology and population biology. Annu. Rev. Ecol. Syst. 22: 95-114.

Warwick, S.I., and L.D. Black. 1981. The relative competitiveness of atrazine susceptible and resistant populations of Chenopodium album and C. strictum. Can. J. Bot. 59: 689-693.

Warwick, S.I., and P.B. Marriage. 1982. Geographical variation in populations of Chenopodium album resistant and susceptible to atrazine. I. Between- and within-population variation in growth and response to atrazine. Can. J. Bot. 60: 483493.
Watson, D., A.M. Mortimer, and P.D. Putwain. 1987. The seed bank dynamics of triazine resistant and susceptible biotypes of Senecio vulgaris - implications for control strategies. Proc. Br. Crop Prot. Conf. - Weeds 3: 917-924.

Weaver, S.E., and A.G. Thomas. 1986. Germination responses to temperature of atrazine-resistant and -susceptible biotypes of two pigweed (Amaranthus) species. Weed Sci. 34: 865-870.

Weaver, S.E., and S.I. Warwick. 1982. Competitive relationships between atrazine resistant and susceptible populations of Amaranthus retroflexus and $A$. powellii from southern Ontario. New Phytol. 92: 131-139.

Weaver, S.E., S.I. Warwick, and B.K. Thompson. 1982. Comparative growth and atrazine response of resistant and susceptible populations of Amaranthus from southern Ontario. J. Appl. Ecol. 19: 611620.

Zanin, G., and M. Lucchin. 1990. Comparative growth and population dynamics of triazine-resistant and susceptible biotypes of Solanum nigrum $\mathrm{L}$. in relation to maize cultivation. J. Genet. Breed. 44: 207-216. 